\title{
Biocontrol potential of bacteriophage $\phi s p 1$ against bacterial wilt-causing Ralstonia solanacearum in Solanaceae crops
}

\author{
Pramila Devi Umrao, Vineet Kumar and Shilpa Deshpande Kaistha* ${ }^{*}$
}

\begin{abstract}
Background: Bacteriophages are effective biocontrol strategy as well as ecofriendly remedy for the emerging antibiotic and chemical resistance in bacterial phytopathogens such as bacterial wilt-causing Ralstonia solanacearum. One of the major challenges in the use of bacteriophage therapy for agricultural phytopathogens is maintaining their viability even during variations in $\mathrm{pH}$, temperature, ultraviolet irradiation, and desiccation during field application for sustainable agriculture.

Results: In this study, the isolation and characterization of phage $\phi s p 1$ for its efficacy against wilt-causing $R$. solanacearum performed on Solanum lycopersicum (tomato) seedlings and Solanum tuberosum (potato) tuber assay are reported. Bacteriophage was found to be viable and stable at a wide $\mathrm{pH}$ range (3.0-9.0) and at temperatures up to $55^{\circ} \mathrm{C}$. Phage $\phi s p 1$ required $\sim 15$ min for adsorption and completed its life cycle in 25-30 min by host cell lysis with a burst size of $\sim 250-300$. Phage $\phi s p 1$ eradicated $94.73 \%$ preformed $R$. solanacearum biofilm and inhibited biofilm formation by $73.68 \%$ as determined by the static crystal violet microtiter biofilm assay. Transmission electron microscope revealed the phage $\phi s p 1$ to be approximately $208 \pm 15 \mathrm{~nm}$ in size, comprising of icosahedral head (100 $\pm 15 \mathrm{~nm}$ ) and tail, as belonging to Myoviridae family. Plant bioassays showed 81.39 and $87.75 \%$ reduction in pathogen count using phages $\phi s p 1$ in potato tuber and tomato seedlings, respectively. Reversal in disease symptoms was $100 \%$ in phage-treated tuber and tomato plant (pot assay) compared to only pathogen-treated controls.

Conclusion: Isolated bacteriophage $\phi s p 1$ was found to be highly host specific, effective in biofilm prevention, and capable of inhibiting bacterial wilt at low multiplicity of infection (1.0 MOl) in tomato as well as potato tuber bioassays. Phages $\phi \mathrm{sp} 1$ were environmentally stable as they survive at variable $\mathrm{pH}$ and temperature. Bacteriophage $\phi s p 1$ shows a promise for development into a biocontrol formulation for the prevention of $R$. solanacearum bacterial wilt disease.
\end{abstract}

Keywords: Bacterial wilt, Bacteriophage, Biocontrol, Biofilm, Potato tuber, Tomato seedlings

\section{Background}

Ralstonia solanacearum has been categorized as the second most devastating pathogen causing bacterial wilt in crops of mainly the Solanaceae family worldwide (Ramesh et al. 2014). It is a Gram-negative bacterial phytopathogen with a wide host range of over 200 different

\footnotetext{
*Correspondence: shilpakaistha@csjmu.ac.in

Department of Microbiology, Institute of Biosciences \& Biotechnology, Chhatrapati Shahu Ji Maharaj University, Kanpur, UP 208024, India
}

crops (Álvarez et al. 2010). R. solanacearum has been recently reclassified into three distinct species, namely, $R$. solanacearum (phylotype II), $R$. pseudosolanacearum (phylotypes I and III), and $R$. syzygii (phylotype IV), that have different host ranges and geographic origin/distribution (Safni et al. 2014). Following infection, the pathogen enters through damaged plant systems and colonizes the vascular tissue, secreting copious amounts of exopolysaccharides, blocking water uptake, and

\section{Springer Open}

(ㅇ The Author(s). 2021 Open Access This article is licensed under a Creative Commons Attribution 4.0 International License, which permits use, sharing, adaptation, distribution and reproduction in any medium or format, as long as you give appropriate credit to the original author(s) and the source, provide a link to the Creative Commons licence, and indicate if changes were made. The images or other third party material in this article are included in the article's Creative Commons licence, unless indicated otherwise in a credit line to the material. If material is not included in the article's Creative Commons licence and your intended use is not permitted by statutory regulation or exceeds the permitted use, you will need to obtain permission directly from the copyright holder. To view a copy of this licence, visit http://creativecommons.org/licenses/by/4.0/. 
causing xylem destruction. This results in wilting of leaves and stem and eventual collapse and death of the plant (Yadeta and Thomma 2013). Control of the phytopathogen is difficult due to increasing resistance of the organisms to traditional control mechanisms such as copper, pesticides, and antibiotic treatments. Other treatments that have been studied for its control include the use of antagonistic metabolites producing rhizosphere, endophytic bacteria, fungi and endophytes, organic residues, and various soil amendments (Yuliar and Toyota 2015).

Most control strategies become ineffective in controlling biofilm forms of growth which contribute to the virulence of the phytopathogen. Biofilm formation is the ability of the pathogen to form communities enclosed within an exopolymeric substance (EPS) that protects it from various stresses. This ability to form biofilm can protect the pathogen from plant defenses as well as external control measures (Mina et al. 2019). Mori et al. (2018) have reported the ability of $R$. solanacearum strain OE1-1 to form mushroom type of biofilms within intercellular spaces in tomato plant root and stem. Many biofilm factors such as sugars (ralfuranones) and extracellular nucleases contributed to $R$. solanacearum virulence (Minh Tran et al. 2016; Mori et al. 2018).

Bacteriophages, viruses that are intracellular parasites of bacterial cells, that can penetrate biofilms and cause lysis of phytopathogens are a promising biocontrol strategy (Kaistha et al. 2018). The control of many bacterial phytopathogenic agents such as Pseudomonas syringae, Xanthomonas campestris, $X$. axonopodis, Pectobacterium carotovorum, Dickeya solani, and Erwinia amylovora has been reported using bacteriophage (Buttimer et al. 2017). For the effective biocontrol of bacterial phytopathogen, lytic phages are particularly useful due to their ability to cause targeted lysis of host cells, their abundance in nature, environmental non-toxicity, and the auto-dosing effect (Kaistha et al. 2018). Many studies have isolated and characterized $R$. solanacearum bacteriophages. These include temperate phages responsible for enhanced virulence, lytic phages that have demonstrated effective biocontrol as well as phages with no demonstrable biocontrol effect in plant assay studies (Álvarez and Biosca 2017). Phage PE226 having the properties of lytic and lysogeny both exhibited virulence towards R. solanacearum (Murugaiyan et al. 2011). Another phage Rs551 demonstrated diminished virulence stress of $R$. solanacearum race 3 biovar 2 by decreasing exopolysaccharide production (Ahmad et al. 2017). On the other hand, RSS1 a filamentous phage enhanced virulence of phytopathogen $R$. solanacearum upon infection. This was attributed to induction of virulence factors such as extracellular polysaccharide (EPS) synthesis and twitching motility, leading to early wilting in tomato plants (Addy et al. 2012). Recently, bacteriophage, namely, RsoM1USA, infecting $R$. solanacearum strain RUN302 significantly reduced growth of the infected bacterium in vitro but was unable to reduce virulence in tomato plants, as compared to uninfected strain (Addy et al. 2019). In the Indian context, in vitro phage lytic activity against $R$. solanacearum has been reported (Barua and Nath 2019). There are however, to the best of our knowledge, no studies that report phages capable of inhibiting biofilm formation in $R$. solanacearum and acting as an effective biocontrol agent using plant bioassays.

Herein, isolation of lytic bacteriophage sp1 against R. solanacearum strain 1629 that is capable of inhibiting and eradicating $R$. solanacearum biofilms was report. In order to test the phage in field applications, its sensitivity to variations in $\mathrm{pH}$, temperature, and ultraviolet radiation was characterized. The biocontrol efficiency of bacteriophages was demonstrated through plant bioassays performed on Solanum lycopersicum (tomato) seedlings and $S$. tuberosum (potato) tuber slice.

\section{Methods}

Bacterial strains and culture conditions

$R$. solanacearum strain F1C1 (obtained from Dr Suvendra Roy, Department of Molecular \& Biotechnology, Tezpur University, Assam) and $R$. solanacearum (NAIMCC-F01629) stock cultures were maintained at $-20{ }^{\circ} \mathrm{C}$ and propagated on the tryptone soy agar (TSA) or casamino acid-peptone glucose (CPG) (Hi Media, India) at 28 to $30^{\circ} \mathrm{C}$. 2,3,5-Triphenyl tetrazolium chloride (TTC) medium (Hi Media, India) was used for differentiating virulent colony from non-virulent or mutant type colonies.

\section{Isolation and characterization of bacteriophages Sampling and isolation of bacteriophage}

Bacteriophages were isolated from soil samples collected from rhizosphere of different cultivars of solanaceous crops from Kanpur and Fatehpur, Uttar Pradesh, India. Soil sampling was carried out preferentially in April (summer season) and July (after precipitation). For phage enrichment, soil pool collected from various cultivars was mixed well. Five grams of soil were dissolved in 10 $\mathrm{ml} 1 \mathrm{X}$ phosphate-buffered saline (PBS) in 45-ml Falcon tube by vigorous shaking to release phages from soil particles, centrifuged $\left(10,000 \mathrm{rpm}\right.$ for $10 \mathrm{~min}$ at $\left.4^{\circ} \mathrm{C}\right)$, supernatant collected, and filtered through PES membrane syringe $(0.45-\mu \mathrm{m}$ pore size) (Hi Media Pvt. Ltd. India). Plaque assay was performed using double-layer agar (DLA) overlay method (Kropinski et al. 2009). Equal aliquots of log phase host bacteria $R$. solanacearum strain 1629 (NAIMCC-F01629) and phage filtrate (100 $\mu \mathrm{l})$ were mixed in $0.3-0.4 \%$ soft agar and poured over a $1.5 \%$ 
hard agar plate in TSA media. Specificity of isolated phages was also checked against $R$. solanacearum strain F1C1 by employing DLA. Plate was incubated at $30 \pm 2^{\circ} \mathrm{C}$ for 24 to $48 \mathrm{~h}$ for observing plaque formation.

\section{Bacteriophage purification and propagation}

Isolated bacteriophages were purified through single successive plaque isolation and propagated by picking a well-separated plaque with the help of a sterile inoculation loop and inoculated into $200 \mathrm{ml}$ TSB medium, containing overnight grown log culture of $10^{9}$ host cells and incubated at $30 \pm 2^{\circ} \mathrm{C}$ at $140 \mathrm{rpm}$ for phages stock preparation.

The phage suspension was centrifuged (10,000 rpm, 10 $\min , 4^{\circ} \mathrm{C}$ ), filter sterilized, and treated with chloroform $(1 \% \mathrm{v} / \mathrm{v})$ to remove bacterial contamination. High titer phage purification was further conducted by using PEG8000 method with some modification in SM buffer (50 mmol L ${ }^{-1}$ Tris- $\mathrm{HCl}$ at $\mathrm{pH} 7.4,100 \mathrm{mmol} \mathrm{L}^{-1} \mathrm{NaCl}, 10$ $\mathrm{mmol} \mathrm{L}^{-1} \mathrm{MgSO}_{4}$, and $0.01 \%$ gelatin) (Yamamoto et al. 1970). Purified concentrated phages were stored in aliquots at $-20^{\circ} \mathrm{C}$ for long-term storage. Short-term stock preparations were maintained at $4^{\circ} \mathrm{C}$ for further use.

\section{Spot assay and double-layer agar (DLA) overlay assay}

To check phage viability, spot assay was carried out. Briefly, phage suspension was serially diluted, and $10 \mu \mathrm{l}$ diluted phage was spot inoculated on molten agar $(0.4 \%$ agar, w/v) containing host cells of $10^{7} \mathrm{CFU} \mathrm{m} \mathrm{m}^{-1}$. Clear zones of plaques were observed after incubating the plates overnight at $30 \pm 2^{\circ} \mathrm{C}$. Further, the phage titer was determined by plaque assay by employing DLA technique as described previously (Kropinski et al. 2009).

\section{Adsorption assay, one-step growth curve}

Adsorption assay and one-step growth curve were performed with some modification (Delbrück 1940). Adsorption time and burst size for phages $\phi$ sp1 were determined. An equal amount of phages (titer $10^{6}$ ) and bacterial suspension was taken, incubated for $5 \mathrm{~min}$, diluted $\left(1: 10^{2}\right)$, and DLA performed at 5 min intervals till $30 \mathrm{~min}$ in order to determine the phage titer.

\section{Temperature, $\mathrm{pH}$, and UV irradiation sensitivity}

Thermostability of bacteriophage was determined by incubating phage titer $10^{6} \mathrm{PFU} \mathrm{ml}{ }^{-1}$ for $10 \mathrm{~min}$ at 37,45 , and $55^{\circ} \mathrm{C}$ with intermittent shaking as per protocol of Sagar et al. (2017). For the determination of pH stability, the same titer was incubated at $\mathrm{pH}$ 3.0, 5.0, 7.0, and 9.0 for $20 \mathrm{~min}$ (Sagar et al. 2017). For UV irradiation sensitivity, phage titer $10^{6} \mathrm{PFU}$ was exposed to UV C irradiation (UV254 nm) for 5, 10, and $15 \mathrm{~min}$. The treatments were followed by DLA as described previously.

\section{Host range}

Host range of phage $\phi$ sp1 was tested by performing spot assay against $R$. solanacearum isolates RS1, RS2, RS3, and RS4 isolated from stem of potato plants collected from agricultural fields and $R$. solanacearum strain F1C1. Rhizospheric bacterial hosts such as $P$. aeruginosa ATCC 15442, P. aeruginosa R32 and GD2 (obtained from Department of Microbiology, CSJMU University, Kanpur) were also used to determine host specificity.

\section{Transmission electron microscopy}

Transmission electron microscope (TEM) observation to study bacteriophage morphology was performed with some modifications (Goodridge et al. 2003). High titer purified phage suspension in SM buffer was dropped on copper-coated grids (diameter, $3 \mathrm{~mm}$; 300 meshes) and allowed to adsorb for $5 \mathrm{~min}$. The bacteriophage particles were stained by the addition of $2 \%(\mathrm{w} / \mathrm{v})$ phosphotungstic acid (PTA) for $10 \mathrm{~s}$. The grid was allowed to dry for $20 \mathrm{~min}$ and examined under a TEM (FEI Tecnai S Twin) at $200 \mathrm{kv}$ (SAIF, AIIMS, Delhi, India).

\section{Scanning electron microscopy}

Biofilm development on glass cover slip surfaces was visualized by scanning electron microscopy (SEM) with some modification (Sagar et al. 2017). Cover slip was washed gently in sterile $1 \mathrm{X}$ phosphate-buffered saline (PBS) to remove planktonic cells, fixed in $5 \%(\mathrm{v} / \mathrm{v})$ glutaraldehyde in PBS buffer for $2 \mathrm{~h}$, followed by fixing with post-fixative $1 \%$ osmium tetroxide. This was followed by dehydration steps through a graded series of 10-min ethanol immersions (30, 50, 70, 90, and 100\%). Specimens were mounted on aluminum stubs and observed on SEM (SM 6490, BBAU, Lucknow, UP, India). The entire cover slip surface was examined, and images were chosen that represented the typical field of view.

\section{Biofilm assay}

Effect of phage treatment on biofilm inhibition was determined using crystal violet biofilm microtiter assay (Umrao et al. 2020). Briefly, log phase $10^{6} \mathrm{CFU}$ $\mathrm{ml}^{-1} R$. solanacearum strain 1629 was simultaneously treated by phage $\phi s p 1$ for biofilm formation assay, while 24-h preformed biofilms were phage treated at 1.0 multiplicity of infection (MOI) for biofilm eradication assay. Post $48 \mathrm{~h}$ incubation, the biofilm was washed with $1 \mathrm{X}$ PBS and stained with $(1 \% \mathrm{w} / \mathrm{v})$ crystal violet for $20 \mathrm{~min}$. Excess stain was removed, plates washed with PBS, and dimethyl sulfoxide (DMSO) was used to solubilize crystal violet-stained biofilm. Results were evaluated by using spectrophotometry (Thermo Scientific Multiscan EX, USA). 


\section{Plant bioassay}

Plant bioassay study was carried out, using Solanum lycopersicum (tomato seedlings and plants) and in $S$. tuberosum (potato tuber slices).

\section{Solanum lycopersicum (tomato) seedling assay}

Variety S-22 of tomato seeds were selected and sterilized with $70 \%$ ethanol, grown on sterile wet cotton bed on plastic tray (Singh et al. 2018). The tray was covered up to maintain humidity and accessibility of light for seed germination in the month of November. Seedling started appearing from the 5 th day onwards. Tomato seedlings of $4-5 \mathrm{~cm}$ in height with two cotyledon leaves were used for pathogenicity test. The experiment was designed for 2.0-ml microcentrifuge tubes with phosphate buffer containing pathogen of $10^{8} \mathrm{CFU} \mathrm{ml}{ }^{-1}$ for pathogenicity by root inoculation method (Singh et al. 2018). Phage $\phi s p 1$ (1.0 MOI) was used for biocontrol, and untreated tomato seedlings in phosphate buffer were used as control. The experiment was performed in triplicates. The seedlings were observed daily, and disease parameters included wilting of stem and leaves. Fresh weight of the infected, treated, and control seedlings was measured at $72 \mathrm{~h}$ post-inoculation. Spectrophotometric reading of cell suspensions in microcentrifuge tubes containing the tomato seedling was taken at $620 \mathrm{~nm}$ (Thermo Scientific Multiscan EX, USA).

\section{Solanum lycopersicum (tomato) pot assay}

Plant bioassay study was undertaken to check bacteriophage biocontrol efficiency and persistence of phage by using soil-drenching method in greenhouse setup in pots containing $250 \mathrm{~g}$ per pot (soil, sand, coconut fiber in 20 : 4:1). Tomato plants (variety S-22) of 5-6-cm length in triplicate were used for the experiment. The base of plant's stem was scratched by a sterilized needle, and plants were inoculated by $20 \mathrm{ml}$ of $10^{8} \mathrm{CFU} \mathrm{ml} \mathrm{m}^{-1} R$. solanacearum strain $1629\left(8 \times 10^{6} \mathrm{CFU} \mathrm{g}^{-1}\right)$ and treated with phage $\phi s p 1$ (1.0 MOI) poured around tomato seedlings in the soil. Disease symptoms of tomato plants were recorded twice in a week by using wilting grade scale according to Kempe and Sequerie (1983). Grade 1, $25 \%$ plant leaves wilted; grade 2, 26-50\% of plant leaves wilted; grade $3,51-75 \%$ plant leaves wilted; grade $4,76 \%$ or more plant leaves wilted and stem collapses; and grade 5, death of plants (Kempe and Sequeira 1983). All experiments were performed in triplicates.

\section{Solanum tuberosum (potato) tuber slices assay}

The experiment was designed for direct inoculation method on potato tuber slices to check phage biocontrol efficiency against $R$. solanacearum strain 1629 as described previously (Champoiseau et al. 2009). Surfacesterilized (70\% ethanol) potato tuber was pieced into slices $\left(4.0 \times 3.5 \times 0.6 \mathrm{~cm}^{3}\right)$ and inoculated with $10^{8} \mathrm{CFU}$ $\mathrm{ml}^{-1}$ of host $R$. solanacearum strain 1629 for pathogenicity control. Host + phage $\phi s p 1$ (1.0 MOI), phage $\phi s p 1$ (1.0 MOI), and uninoculated tuber slices were also incubated at $28^{\circ} \mathrm{C}$ under daily observation. The experiment was performed in triplicate. Diseased symptoms which included vascular browning, bacterial ooze, and tuber necrosis were recorded daily up to day 10 postincubation. Grading scale used for qualitative measure of tuber disease symptoms was as follows: grade 0, no symptoms; grade 1, yellow discoloration, no ooze, and no necrosis; grade 2, brown discoloration, no ooze, softening of tissue at center of lesion but hard to scoop or pick with inoculating loop; grade 3 , brown discoloration with ring formation, whitish ooze from tuber, necrotic tissue softening which is easy to scoop; and grade 4, dark brown-blackish discoloration within the ringed lesion, copious whitish ooze from lesion, total tissue necrosis which is easy to scoop.

Standard plate count was performed at day 10 by plating $(100 \mu \mathrm{l})$ of $\left(0.1 \mathrm{~g} \mathrm{ml}^{-1}\right)$ infected inoculated tuber slices and control tubers. Colony count was recorded after plating for $48 \mathrm{~h}$ at $28^{\circ} \mathrm{C}$ incubation. Cell density of infected tuber tissue solution $\left(0.1 \mathrm{~g} \mathrm{ml}^{-1}\right)$ was also quantified by spectrophotometry (A620nm) (Thermo Scientific Multiscan EX, USA). The presence of $R$. solanacearum was confirmed by simple staining with crystal violet using bright field microscopy.

\section{Ethics approval and consent to participate}

Not applicable.

\section{Statistical analysis}

Statistical analysis was done using Student's $t$ test. All experiments were repeated at least twice in triplicates. $p \leq 0.05$ was considered as biologically significant.

\section{Results}

Isolation and characterization of bacteriophages

Lytic bacteriophages having ability to infect bacterial wilt-causing $R$. solanacearum ( $\phi \mathrm{sp} 1, \phi \mathrm{S} 1, \phi \mathrm{S} 2, \phi \mathrm{S} 3, \phi \mathrm{S} 4$, $\phi \mathrm{V} 3, \phi \mathrm{P} 1, \phi \mathrm{P} 2, \phi \mathrm{P} 3$, and $\phi \mathrm{P} 4)$ were isolated from solanaceous cultivar's rhizosphere soil samples from Kanpur and Fatehpur regions. Phage isolation was performed using DLA with different dilutions of the soil samples. Twelve phages of different plaque morphology were isolated, out of which $\phi \mathrm{sp} 2$ was turbid 1-2 $\mathrm{mm}$ plaque size, $\phi \mathrm{W}$ was pinpoint, and the rest were of clear characteristics (Table 1). Turbid and pinpoint plaque morphology phages were screened to be lysogenic and not considered for further characterization. Phage $\phi s p 1$ was selected for further research based on its clear and consistent lytic activity against a wide host range of $R$. solanacearum spp. One clear large size plaque $(4-5 \mathrm{~mm})$ of $\phi s p 1$ was 
Table 1 List of isolated bacteriophages for host Ralstonia solanacearum strain 1629 used in this study

\begin{tabular}{lllll}
\hline Phage name & Location (district) & Source & Plaque morphology & Phage type \\
\hline$\phi$ sp1 & Fatehpur & Mixed soil pool & Clear, 4-5mm & Lytic \\
$\phi$ sp2 & Fatehpur & Mixed soil pool & Turbid, 1-2mm & Lysogenic \\
$\phi S 1$ & Fatehpur & Tomato field soil & Clear, 2-3mm & Lytic \\
$\phi S 2$ & Fatehpur & Tomato field soil & Clear, 2-3mm & Lytic \\
$\phi S 3$ & Fatehpur & Tomato field soil & Clear, 2-3mm & Lytic \\
$\phi S 4$ & Fatehpur & Tomato field soil & Clear, 2-3mm & Lytic \\
$\phi V 3$ & Kanpur & Water & Clear, 2-3mm & Lytic \\
$\phi W$ & Kanpur & Water & Cinpoint & Lysogenic \\
$\phi P 1$ & Kanpur & Potato field soil & Lytic \\
$\phi P 2$ & Kanpur & Potato field soil & Clear, 2-3mm & Lytic \\
$\phi P 3$ & Kanpur & Potato field soil & Clear, 2-3mm & Lytic \\
$\phi P 4$ & Kanpur & Potato field soil & turbid, 2-3mm & Lytic \\
\hline
\end{tabular}

purified and concentrated as described previously and confirmed using the spot test and double layer agar overlay assay (Fig. 1a, b, and c).

Morphological characteristics of phage $\phi s p 1$, using TEM imaging, was found to be of long contractile tailed virus with icosahedral head $85 \pm 10 \mathrm{~nm}$ and $208 \pm 10 \mathrm{~nm}$ in size (Fig. 1d). Bacteriophage $\phi$ sp1 morphology resembles phages belonging to Myoviridae family containing ds DNA classified under Caudovirales. Based on these characteristic, phage $\phi \mathrm{sp} 1$ was designated as $\mathrm{vB}_{-}$ RsoMSP1 (Ackermann 2011; Adriaenssens and Brister 2017). Phage $\phi s p 1$ was further characterized by one-step growth curve and adsorption assay. These phages took $\sim 15$ min for adsorption and completed their life cycle in 25-30 min by lysis of the host cell with a burst size of 250-300 (Fig. 2a).

\section{Stability characterization of bacteriophage $(\mathrm{pH}$,} temperature, and UV)

Bacteriophage $\phi s p 1-$ based biocontrol of $R$. solanacearum is an effective measure of controlling the phytopathogen.
However, environmental factors such as $\mathrm{pH}$, temperature, desiccation, and UV irradiation limited the phage survivability and persistence in the agriculture soil (Jones et al. 2018). Phage $\phi s p 1$ isolated from solanaceous cultivar's rhizosphere soil against $R$. solanacearum was found to be stable at temperature up to $55^{\circ} \mathrm{C}$ and a wide $\mathrm{pH}$ range of 3-9 (Fig. $2 \mathrm{~b}$ and c). Optimal lytic activity of $\phi s p 1$ was found at neutral $\mathrm{pH}$ and temperature $37^{\circ} \mathrm{C}$, which decreased by increasing temperature and decreasing plaque size (Fig. 2b). The loss of virus viability was more than $36.84 \%$ at $45^{\circ} \mathrm{C}$ in laboratory condition. However, phage $\phi \mathrm{sp} 1$ demonstrated viability at variable $\mathrm{pH}(3-9)$ in acidic and alkaline condition, but with reduced plaque sizes (Fig. 2c). The burst size of phage decreased in acidic and alkaline $\mathrm{pH}$ as well as increasing temperature, but phage infectivity was not affected. Hence, phage фsp1 survival will not be affected drastically with changes in rhizospheric soil $\mathrm{pH}$ and temperature and help keep the bacterial population under control. Phage $\phi$ sp1 was however drastically affected by UV

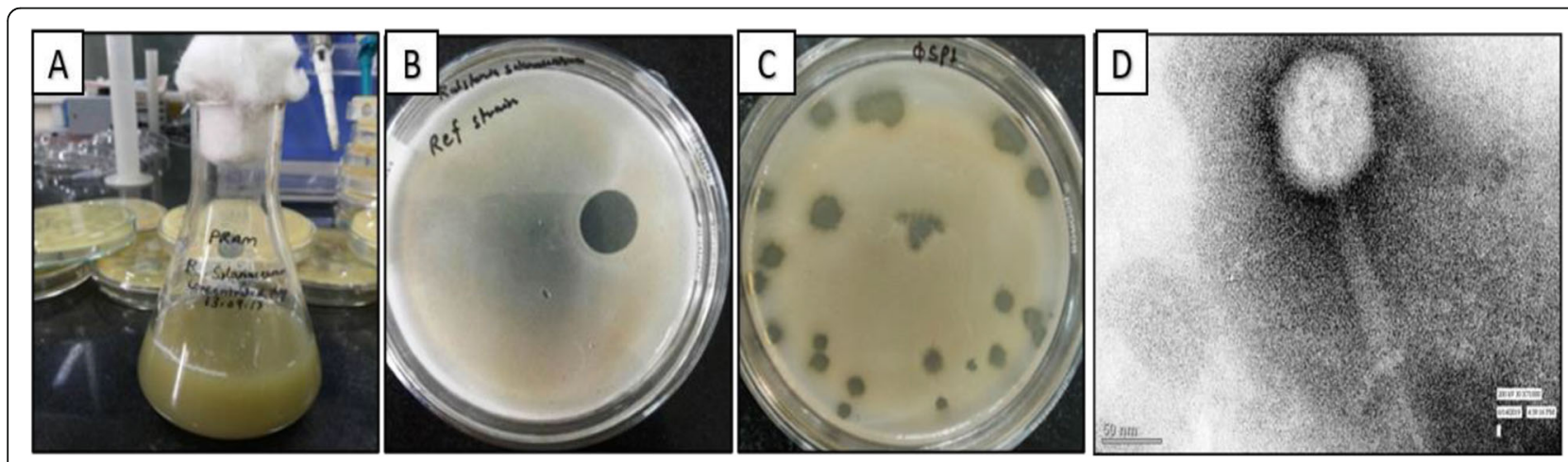

Fig. 1 Isolation and characterization of phage $\phi s p 1$ against host Ralstonia solanacearum strain 1629. a Propagated phages stock. b Spot test. c $\phi s p 1$ plaques on double-layer agar plate. d TEM image of phage $\phi s p 1$ morphology at 200kv $\times 71000$ 


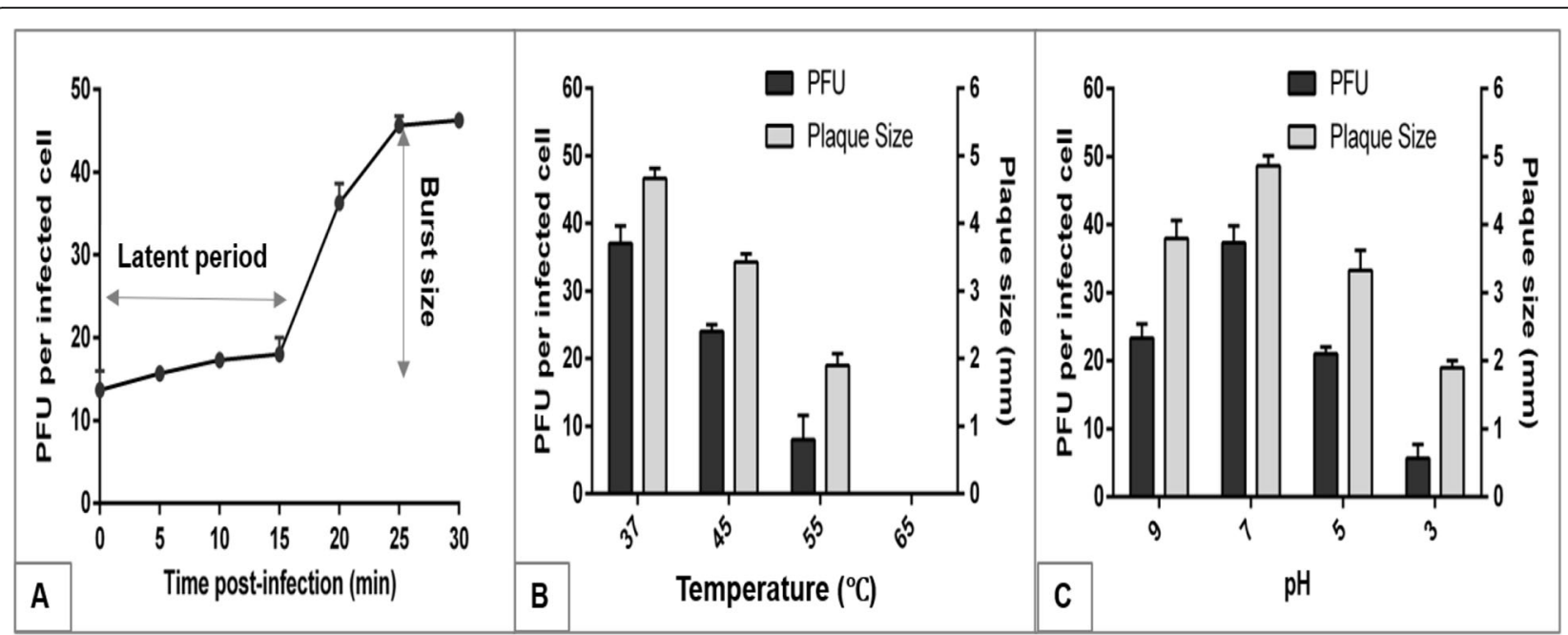

Fig. 2 One-step growth curve and stability characterization of phage $\phi s p 1$ growing on Ralstonia solanacearum strain 1629 at varying growth temperatures and $\mathrm{pH}$. a Phage $\phi$ sp1 PFUs per infected cell at 5-min interval post-infection up to 30 min with dilution factor $10^{2}$. Phage titer was determined by performing DLA. Latent period $15 \mathrm{~min}$ and burst size of virus 250-300. b The relative number and size of visible plaques under different temperature conditions were compared for phage variability. c Phage $\phi s p 1$ stability at variable pH range 3-9 plaque size deceased in acidic and alkaline conditions

C irradiation $(254 \mathrm{~nm})$ as no plaques were observed in UV-treated DLA plates.

\section{Host range determination}

Host range of phage $\phi s p 1$ was determined by spot assay on different bacteria such as plant growth promoting Pseudomonads and $R$. solanacearum RS1, RS2, RS3, RS4. R. solanacearum strain 1629 was used as positive control (Table 2). Positive spot assay with $R$. solanacearum strain F1C1 indicated biovar similarity between $R$. solanacearum strain 1629 and strain F1C1. Phage $\phi s p 1$ can be a good candidate as biocontrol agent, as it showed no lytic activity against plant growth promoting Pseudomonas GD2 and Pseudomonas R32 and can be safely used without affecting beneficial soil microflora present in rhizosphere and

Table 2 Host range determination for phage $\phi$ sp 1 on different Ralstonia solanacearum strains and plant growth-promoting bacteria (PGPB)

\begin{tabular}{lll}
\hline Sr No & Host & Spot assay \\
\hline 1. & R. solanacearum 1629 & + \\
2. & R. solanacearum F1C1 & + \\
3. & R. solanacearum RS1 & - \\
4. & R. solanacearum RS2 & - \\
5. & R. solanacearum RS3 & - \\
6. & R. solanacearum RS4 & - \\
7. & Pseudomonas aeruginosa ATCC 15442 & - \\
8. & Pseudomonad GD2 (PGPB) & - \\
9. & Ps. aeruginosa R32 (PGPB) & - \\
\hline
\end{tabular}

host plants. The data also indicated that the phages are host specific for $R$. solanacearum and can be useful for diagnosis purpose using phage typing. Due to specificity against targeted host, bacteriophages can be used as diagnostic tools for plant pathogenic bacterial species ( $\mathrm{Vu}$ and $\mathrm{Oh} 2020)$.

\section{Bacteriophage $\phi s p 1$ biocontrol efficacy against wilt pathogen $R$. solanacearum Application of bacteriophages in biofilm inhibition}

One of the potent pathogenicity factors of bacterial wilt-causing $R$. solanacearum is its ability to form biofilms (Mori et al. 2016). Efficacy of phage $\phi s p 1$ in inhibiting biofilm formation by $R$. solanacearum strain 1629 by using SEM as well as in static biofilm assay was tested. $R$. solanacearum was found to be a strong biofilm former, and phage $\phi s p 1$ infection inside the biofilm was characterized by scanning electron microscopy (SEM). In the presence of phage $\phi$ sp1, bacterial cells appear to be shrunken, and the surface ruptured unlike untreated control cells (Fig. 3a, b, c, and $\mathrm{d}$ ).

Using the static crystal violet assay, 73.68 and $94.73 \%$ reduction in biofilm formation and biofilm eradication, respectively, was found when bacterial pathogen was treated by phages (1.0 MOI) (Fig. 3e). Phage $\phi s p 1$ (1.0 MOI) was thus capable of inhibiting biofilm formation and biofilm eradication. Reduction in EPS production decreased bacterial wilt incidence significantly in wiltsusceptible plants, and EPS mutants triggered noticeably less production of defense-associated reactive oxygen species in wilt-resistant tomato plants (Milling et al. 


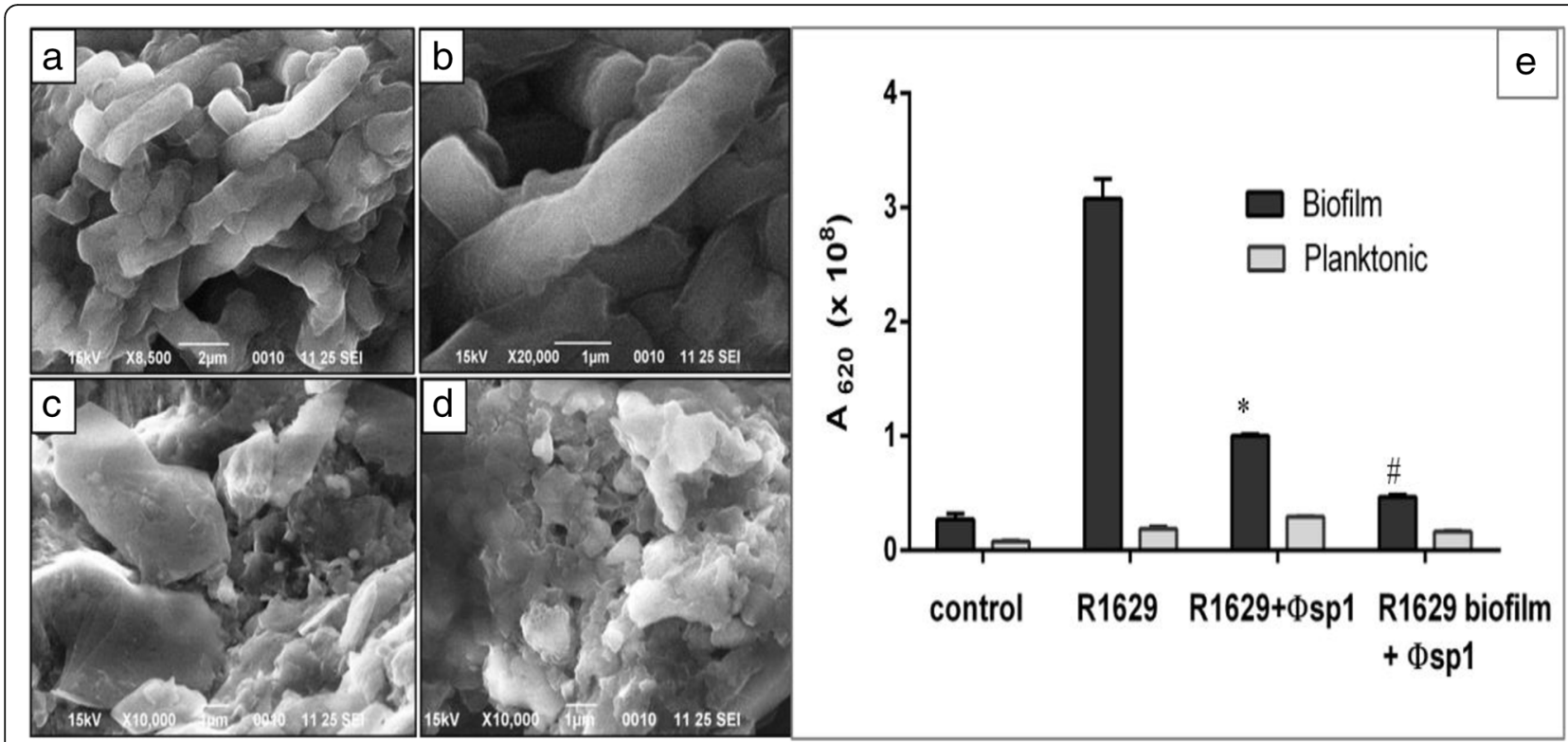

Fig. 3 SEM images of Ralstonia solanacearum strain 1629 biofilm. a Uninfected biofilm $\times 8500$. b Uninfected biofilm at $\times 20,000$. c Biofilm treated with phage $\phi s p 1(1 \mathrm{MOI})$ at $\times 10,000$ showing disrupted cells. d Biofilm treated with phage $\phi s p 1(10 \mathrm{MOI})$ at $\times 10,000$ showing cell debris. e Phage $\phi$ sp1 biocontrol of biofilm formation and eradication of $R$. solanacearum strain 1629 (R1629). ${ }^{*} p \leq 0.0073$ (for biofilm formation), ${ }^{\#} p \leq 0.0017$ (for biofilm eradication) in comparison with phage-untreated R1629 biofilm

2011; Prakasha et al. 2017). Phages are also known to secrete depolymerase enzymes on their capsids, which in addition to host lysis can also degrade biofilm EPS, permitting the phage anti-receptor to gain entry to the receptors on the surface of their host bacterium (Pires et al. 2016).

The present study showed that phage $\phi s p 1$ can be useful for prevention of biofilm formation, a pathogenicity factor of $R$. solanacearum. In addition, phage can also be used as treatment for preformed biofilm that can be eradicated by direct inoculation method.

\section{Phage biocontrol efficacy in plant bioassays}

The efficacy of phage $\phi$ sp 1 treatment on pathogenicity of $R$. solanacearum strain 1629 was demonstrated in tomato seedlings grown on sterilized wet cotton bed on plastic trays as described previously. After $72 \mathrm{~h}$ observation, pathogen-treated tomato

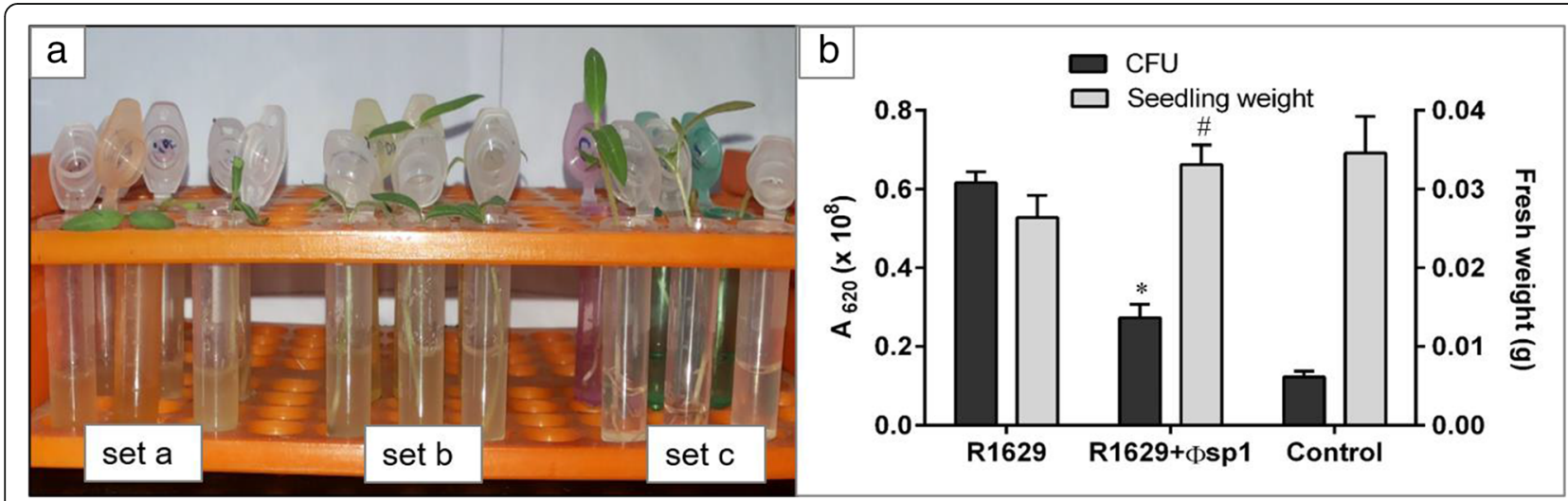

Fig. 4 Phage $\phi s p 1$ biocontrol assay of Ralstonia solanacearum strain 1629 (R1629) on tomato seedlings in vitro. a Phage ( $\phi$ sp1) biocontrol on tomato seedlings in microcentrifuge tubes; set a $-R$. solanacearum strain 1629 inoculated seedling wilted in 72 h, set b-R $1629+\phi s p 1$ (1 MOI) treated seedlings remained healthy, set c-uninoculated buffer control seedlings were found completely healthy. b Phage $\phi$ sp 1 biocontrol efficacy on tomato seedlings after $72 \mathrm{~h}$ treatment. Primary axis shows reduced pathogen count (CFU) in phage $\phi s p 1$-treated R1629-infected tomato seedlings (R1629+ $\phi$ sp1) compared to phage untreated, R1629-infected tomato seedlings $\left({ }^{*} p \leq 0.0024\right)$. Secondary axis shows fresh weight of tomato seedlings in R1629 + фsp1-treated and phage-untreated R1629-infected tomato seedlings (\# $p \leq 0.031$ ). Data are mean values of experiment performed in triplicates with standard deviation 
seedlings containing $10^{8} \mathrm{cfu} \mathrm{ml}^{-1}$ were found to be completely wilted, while phage-treated seedlings showed partial wilting, and buffer control seedlings remained healthy (Fig. 4a). Furthermore, reduction of bacterial load in phage $\phi$ sp1-treated tomato seedlings was calculated at $87.75 \%$ as compared to non-treated pathogen control as evaluated by spectrophotometry. In addition, comparison of fresh weight of tomato seedlings showed biologically statistical difference between phage-treated and non-treated pathogens (Fig. 4b).

In direct inoculation method on tuber slices, diseased symptoms were recorded after 10 days' incubation in pathogen inoculated, while no lesion was found on phage $\phi$ sp1-treated tuber slices. The infected tuber slices showed symptoms of vascular browning and bacterial ooze. The disease symptoms started to appear at $96 \mathrm{~h}$ post-inoculation. By day 10, grade 3.0 disease symptoms with brown vascular discoloration, oozing, and soft tissue collapse were observed in the infected tuber. A slight yellow discoloration with no ooze or tissue necrosis observed for phage-treated infected tuber was scored as grade 1.0 disease symptoms. No such features were observed in control uninoculated tuber. Further, to check the presence of phage, samples were obtained from inoculated infected tuber slice $\left(0.1 \mathrm{~g} \mathrm{ml}^{-1}\right)$ and quantified using the DLA assay (Fig. 5). Up to $81.39 \%$ reduction in bacterial population was found in phage- treated tuber sample confirming the biocontrol potential of phage $\phi \operatorname{sp} 1$ against wilt-causing $R$. solanacearum strain 1629 (Fig. 5). In order to determine phage persistence and pathogen survivability in the tubers, tuber samples were processed for DLA and standard plate count on TTC media respectively. $9.68 \times 10^{10} \mathrm{CFU} \mathrm{g}^{-1}$ bacteria were isolated from pathogen-infected tuber, whereas only $2.5 \times 10^{4} \mathrm{CFU}$ $\mathrm{g}^{-1}$ pathogen was recovered from phage-treated tubers. Phage $2 \times 10^{4} \mathrm{PFU} \mathrm{g}^{-1}$ was reisolated from $R$. solanacearum strain $1629+\phi s p 1$ samples by DLA assay. Further, R. solanacearum or plaques were not isolated from uninfected control tuber (Table 3 ). Similarly, phage application (0.01 MOI) to control Pectobacterium carotovorum ssp. carotovorum and $P$. wasabie destruction prevented damage of up to $80 \%$ on tuber slices and up to $95 \%$ on entire tubers against tissue maceration from combined bacterial infection (Czajkowski et al. 2015).

To confirm phage persistence in soil microcosm, tomato plant bioassay was performed in pots within the greenhouse setup as described in methods. Plants were inoculated with $10^{8} \mathrm{CFU} \mathrm{m} l^{-1} R$. solanacearum strain 1629 on scratched stem cells at day 0 and by soil drenching method on day 7. For biocontrol experiments, plants were inoculated with phage $\phi$ sp1 suspension concentration of 1.0 MOI. At day 10 of second inoculation, pathogen-inoculated tomato plants were found to be stunted, yellowing to browning of the leaves was

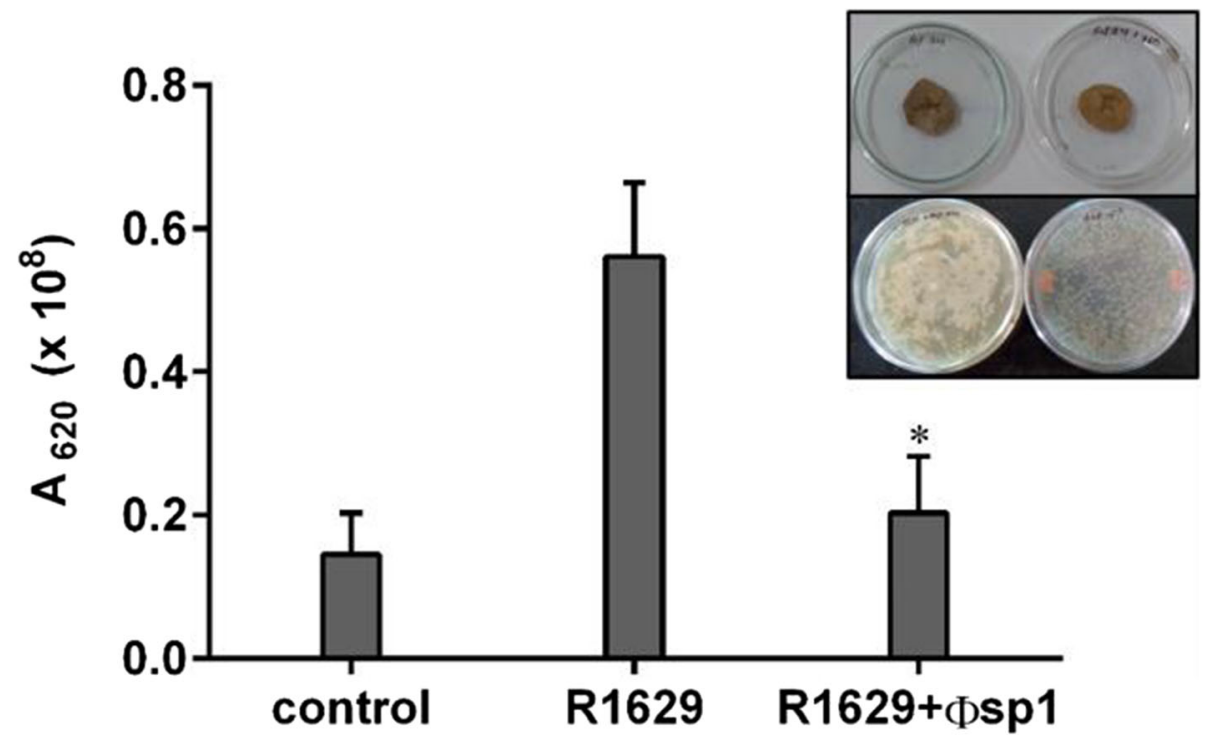

Fig. 5 Pathogenicity of Ralstonia solanacearum strain 1629 (R1629) and phage $\phi s p 1$ biocontrol efficacy on potato tuber slice. In vitro phage $\phi s p 1$ bioassay on potato tuber slices against R1629 and phage-untreated tuber. Plating of reisolated R1629 from phage $\phi$ sp1-treated R1629-infected potato tubers showing plaques on bacterial lawn. Standard plate count for R1629 from same potato tuber slices on TTC medium (figure inset). Reduction in R. solanacearum strain 1629 (R1629) following phage $\phi s p 1$ treatment in inoculated tuber sample suspension (0.1 $\mathrm{g} / \mathrm{ml})$ post 10 days of inoculation. Phage $\phi s p 1+$ R1629 inoculated tuber slices show significantly reduced bacterial population compared to R1629 inoculated $\left({ }^{*} p \leq\right.$ 0.05). Growth measured with optical density (OD) by spectrophotometry absorbance at $620 \mathrm{~nm}\left(1.0 \mathrm{OD}=10^{8}\right.$ cells) 
Table 3 Phage $\phi s p 1$ biocontrol efficacy in potato tuber slice bioassay using Ralstonia solanacearum strain 1629 (R 1629)

\begin{tabular}{|c|c|c|c|c|}
\hline Experimental set-up & Disease symptoms & Grade & $\begin{array}{l}\text { Microbial count CFU } \\
\mathbf{g}^{-1}\end{array}$ & $\begin{array}{l}\text { Phage re-isolated PFU } \\
\mathbf{g}^{-1}\end{array}$ \\
\hline Control & $\begin{array}{l}\text { No vascular discoloration, ooze absent with no change in tissue } \\
\text { architecture }\end{array}$ & 0 & No Ralstonia & No plaques \\
\hline R1629 & $\begin{array}{l}\text { Vascular discoloration with brown ring-like appearance, slimy ooze, } \\
\text { tissue necrosis }\end{array}$ & 3 & $9.68 \times 10^{10}$ & No plaques \\
\hline $\begin{array}{l}\text { R1629 + phage } \\
\text { фsp1 }\end{array}$ & Yellowing, ooze absent, tissue intact & 1 & $2.5 \times 10^{4}$ & $2 \times 10^{4}$ \\
\hline
\end{tabular}

recorded, and two leaves out of six were found to be wilted by $R$. solanacearum strain 1629 . The disease progression was recorded to be at grade 2.0 (Fig. 6). The uninoculated plants (control plants) were found to be healthy plants, and height of the plants at the same day was recorded to be $15-16 \mathrm{~cm}$ with 6 leaves. Phage $\phi s p 1$ $+R$. solanacearum-treated plants were found intact, standing with 6 leaves at $15-16 \mathrm{~cm}$ with no effects of disease symptoms. At 15-day post-infection, the experimental plant sets were reinoculated with $10^{8} \mathrm{CFU} \mathrm{ml^{-1 }}$ $R$. solanacearum strain 1629 with no further phage treatment of plants. Within a week, the pathogen-infected tomato whole plants collapsed resulting in death showing wilting of grade 5.0. However, phage-treated plants were found to remain completely healthy and growing in the same manner as control plants. Hence, phage $\phi s p 1$ showed $100 \%$ control of bacterial wilt symptoms in $R$. solanacearum-infected tomato plants. Furthermore, phage treatment was effective even after subsequent reexposure to pathogen.

\section{Discussion}

The role of bacteriophage-based biocontrol of wiltcausing $R$. solanacearum in India has not been explored widely although it has been studied in other geographical areas with promising results. Myoviridae jumbo phage $\phi R S L 1$ showed a limited growth, penetration, and movement of inoculated $R$. solanacearum by maintaining a sustainable host phage population (Fujiwara et al. 2011). Post-treatment with phage PE204 of Podoviridae family showed delayed development of wilt, whereas simultaneous application was found to completely inhibit disease in tomato plants (Bae et al. 2012). The utilization of 6 lytic phage cocktail applied to the rhizosphere soil of the tomato plants as soil drench resulted in reduced bacterial wilt incidence by around $10-20 \%$

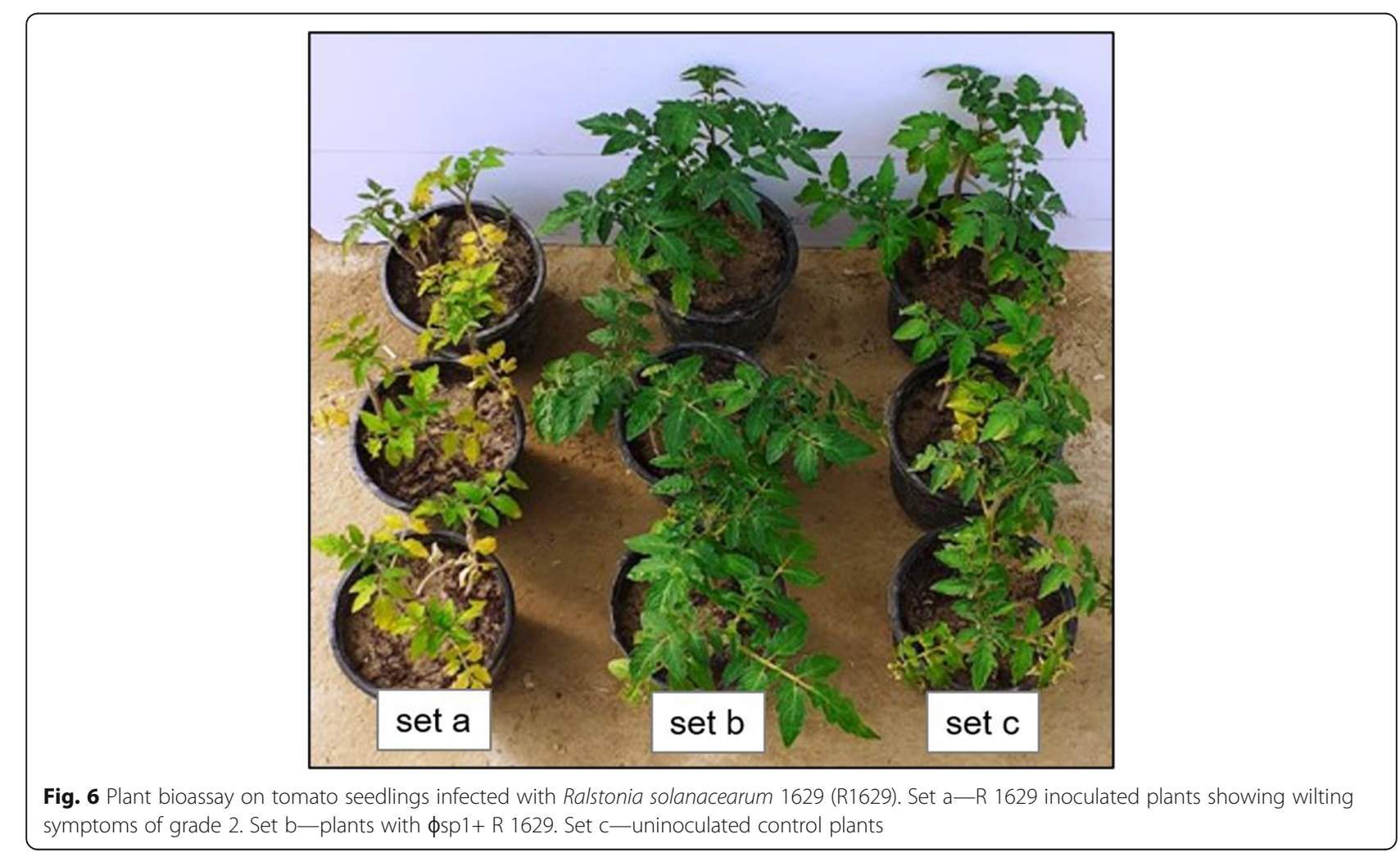


(Kalpage and De Costa 2014). The mixture of two podoviridae bacteriophages (J2 and $\phi \mathrm{RSB} 2$ ) efficiently lysed $R$. solanacearum cells in contaminated soil, while only $\mathrm{J} 2$ phage treatment resulted in disease prevention in tomato plants (Bhunchoth et al. 2015). Podovirus RsPod1EGY, stable at $\mathrm{pH}$ range 5-9 and temperatures up to $60^{\circ} \mathrm{C}$, was shown to suppress $R$. solanacearum in 4week-old tomato seedlings under greenhouse conditions (Elhalag et al. 2018). Phage cocktail (P1) showed diverse inhibition patterns up to $98 \%$ against development of the potato plant wilt-causing $R$. solanacearum (Wei et al. 2017). Recently, the isolation of lytic bacteriophages belonging to T7-like virus genus of Podoviridae was found to be effective in reducing $R$. solanacearum in environmental waters. Watering with one or combination of phages was shown to prevent wilt in more than 300 plants (Álvarez et al. 2019). Different phage combination-treated tomato plants reduced Ralstonia wilt disease incidence by $80 \%$ in greenhouse and field experiments (Wang et al. 2019). These effective biocontrol studies made use of single-phage treatment that was highly stable with strong lytic activity or phage cocktails for effective management of phage resistance and persistence issues. In this study, environmentally stable phage $\phi \mathrm{sp} 1$ demonstrated $R$. solanacearum wilt control in potato tuber, tomato seedlings in buffer media, as well as in tomato plants in soil environment in greenhouse conditions. Further characterization of phage biocontrol efficacy in open field conditions using different formulations for maintaining phage persistence and activity need to be explored.

Bacteriophage-based biocontrol of bacterial wiltcausing $R$. solanacearum in tomato plants depends on phage multiplicity of infection (MOI), plant age as well as variety including environmental factors such as soil type, $\mathrm{pH}$, temperature, moisture content, and presence of organic matter in the soil (Buttimer et al. 2017). Phage population also drastically reduces following UV exposure (Iriarte et al. 2007). In order for phage persistence in the soil, protective formulations can be used which significantly reduce the deleterious effects of environmental stress on phage viability. Non-formulated Ralstonia phage $\phi$ Xacm was found to survive on tomato leaves at $28{ }^{\circ} \mathrm{C}$ at 6 and 8 days but were significantly reduced at 15 and $32^{\circ} \mathrm{C}$. Phage $\phi R S L 1$ was found to be stable in temperature range of $37-55^{\circ} \mathrm{C}$ and effectively limit penetration and movement of $R$. solanacearum strain M4S in tomato plantlings (Fujiwara et al. 2011). Lytic phage PE205 was reported to be stable at wide temperature and $\mathrm{pH}$ range in artificial soil microcosm (Bae et al. 2012). Phages isolated against Ralstonia strain IVIA-1602.1 were found to be stable between 14 and 31 ${ }^{\circ} \mathrm{C}$ at pH 7.0 in a modified Wilbrink broth (MWB) (Álvarez et al. 2019). Obtained results showed that phage фsp1 is environmentally stable, but its survival is significantly reduced in increasing temperatures, $\mathrm{pH}$ extremes, and exposure time of sunlight (exposure up to UV 254 $\mathrm{nm})$. Hence, in order to enhance in-field phage persistence, phage application by soil-drenching method would be most effective and not affected by exposure to UV irradiation (Iriarte et al. 2012). In addition, use of carrier formulations as well as non-pathogenic or avirulent Ralstonia host can be used as strategies for enhancing phage persistence in the soil environment. The ability of phage to survive variations in temperature and $\mathrm{pH}$ makes it a suitable candidate for field applications.

The occurrence of phage-resistant pathogen remains an important issue to address while developing biocontrol phage agents. It is important to measure the dynamics of naturally occurring $R$. solanacearum populations in order to determine the ratio of phage to host for adequate control. It is also recommended to re-isolate it seasonally to obtain newly evolved virulent ones as phage populations tend not to be effective from 1 year to the next. In addition, mutant phages as well as phage cocktails can be used to minimize the occurrence of phage-resistant $R$. solanacearum strains (Buttimer et al. 2017; Ye et al. 2019).

Bacteriophage-based control of pathogens in the form of agricultural biopesticides is garnering support.

\section{Conclusion}

In obtained findings, Myoviridae lytic phage $\phi s p 1$ infecting bacterial population at low multiplicity of infection (1.0 MOI) can be used as an efficient biological control agent against $R$. solanacearum. The phage was found to be highly host specific and, hence, can be efficiently useful in race/biovar determination of $R$. solanacearum. Phages specific to infecting particular races of $R$. solanacearum can also be useful for the development of highly specific phytopathogen diagnostic tools termed as phage typing in contaminated soil or infected plant and vegetables. The potential to reduce the pathogenic wilting activity of $R$. solanacearum in tomato seedlings as well as potato tuber will be helpful to prevent infections in cold storage.

\footnotetext{
Abbreviations

TSA: Tryptone soy agar; TSB: Tryptone soya broth; TTC: Triphenyl tetrazolium chloride; CFU: Colony-forming unit; PFU: Plaque-forming unit;

MOI: Multiplicity of infection; DLA: Double-layer agar; SEM: Scanning electron microscope; TEM: Transmission electron microscope; DW: Distilled water; EPS: Extracellular polysaccharide

\section{Acknowledgements}

We are thankful to SAIF-AIIMS, New Delhi, India, for providing facilities of transmission electron microscopy of virus and USIC department of Babasaheb Bhimrao Ambedkar University, Lucknow, for scanning electron microscopy. We are also thankful to NBAIM, Mau Nath Bhanjan, UP, India, for strain R. solanacearum 1629 (NAIMCC-F01629) and Dr Suvendra Roy, Department of Molecular \& Biotechnology, Tezpur University, Assam, India, for providing F1C1 strain.
} 


\section{Authors' contributions}

PDU performed the experiments and wrote the manuscript. VK helped in the analysis and interpretation of the data regarding graphical representation of the data using software graph pad prism. All the experiments were performed under the supervision and guidance of SDK, who revised and gave final touch in manuscript preparation. All authors read and approved the final manuscript

\section{Funding}

Financial support from UGC, Government of India, to VK (ID 357996) is acknowledged.

\section{Availability of data and materials}

Data and materials given in this study can be used as a reference by other researchers.

\section{Declarations}

Ethics approval and consent to participate

Not applicable.

\section{Consent for publication}

Not applicable.

\section{Competing interests}

The authors declare that they have no competing interests.

\section{Received: 23 November 2020 Accepted: 31 March 2021}

\section{Published online: 14 April 2021}

\section{References}

Ackermann H (2011) Bacteriophage taxonomy. Microbiol Aust 32(2):90-94. https://doi.org/10.1071/MA11090

Addy HS, Ahmad AA, Huang Q (2019) Molecular and biological characterization of Ralstonia phage RsoM1USA, a new species of P2virus, isolated in the United States. Front Microbiol 10:1-14. https://doi.org/10.3389/fmicb.2019. 00267

Addy HS, Askora A, Kawasaki T, Fujie M, Yamada T (2012) The filamentous phage QRSS1 enhances virulence of phytopathogenic Ralstonia solanacearum on tomato. Phytopathology 102(3):244-251. https://doi.org/10.1094/PHYTO-1 0-11-0277

Adriaenssens E, Brister JR (2017) How to name and classify your phage: an informal guide. Viruses 9(4). https://doi.org/10.3390/v9040070

Ahmad AA, Stulberg MJ, Mershon JP, Mollov S, Huang Q (2017) Molecular and biological characterization of $\varphi$ Rs551, a filamentous bacteriophage isolated from a race 3 biovar 2 strain of Ralstonia solanacearum. Plos One 12(9):1-19. https://doi.org/10.1371/journal.pone.0185034

Álvarez B, Biosca EG (2017) Bacteriophage-based bacterial wilt biocontrol for an environmentally sustainable agriculture. Front Plant Sci 8:1-7. https://doi. org/10.3389/fpls.2017.01218

Álvarez B, Biosca EG, López MM (2010) On the life of Ralstonia solanacearum, a destructive bacterial plant pathogen. In: Mendez-Vilas A (ed) Technology and education topics in applied microbiology and microbial biotechnology, pp 267-279

Álvarez B, López MM, Biosca EG (2019) Biocontrol of the major plant pathogen Ralstonia solanacearum in irrigation water and host plants by novel waterborne lytic bacteriophages. Front Microbiol 10:1-17. https://doi.org/1 0.3389/fmicb.2019.02813

Bae JY, Wu J, Lee HJ, Jo EJ, Murugaiyan S, Chung E, Lee S-W (2012) Biocontrol potential of a lytic bacteriophage PE204 against bacterial wilt of tomato. J Microbiol Biotechnol 22(12):1613-1620. https://doi.org/10.4014/jmb.1208. 08072

Barua P, Nath PD (2019) Isolation of bacteriophages infecting Ralstonia solanacearum causing bacterial wilt disease in Naga Chilli (Capsicum chinense Jacq .). Int J Curr Microbiol Appl Sci 8(02):927-937. https://doi.org/10.20546/ ijcmas.2019.802.106

Bhunchoth A, Phironrit N, Leksomboon C, Chatchawankanphanich O, Kotera S, Narulita E, Kawasaki T, Fujie M, Yamada T (2015) Isolation of Ralstonia solanacearum-infecting bacteriophages from tomato fields in Chiang Mai, Thailand, and their experimental use as biocontrol agents. J Appl Microbiol 118(4):1023-1033. https://doi.org/10.1111/jam.12763
Buttimer C, McAuliffe O, Ross RP, Hill C, O'Mahony J, Coffey A (2017) Bacteriophages and bacterial plant diseases. Front Microbiol 8:1-15. https:// doi.org/10.3389/fmicb.2017.00034

Champoiseau P, Jones J, Allen C (2009) Ralstonia solanacearum race 3 biovar 2 causes tropical losses and temperate anxietiese. Plant Heal Prog 10(1):35. https://doi.org/10.1094/PHP-2009-0313-01-RV

Czajkowski R, Ozymko Z, de Jager V, Siwinska J, Smolarska A, Ossowicki A, Narajczyk M, Lojkowska E (2015) Genomic, proteomic and morphological characterization of two novel broad host lytic bacteriophages \$PD10.3 and ФPD23.1 infecting Pectinolytic Pectobacterium spp. and Dickeya spp. Plos One 10(3):e0119812. https://doi.org/10.1371/journal.pone.0119812

Delbrück M (1940) The growth of bacteriophage and lysis of the host. J Gen Physiol 23(5):643-660. https://doi.org/10.1085/jgp.23.5.643

Elhalag K, Nasr-Eldin M, Hussien A, Ahmad A (2018) Potential use of soilborne lytic Podoviridae phage as a biocontrol agent against Ralstonia solanacearum. J Basic Microbiol 58(8):658-669. https://doi.org/10.1002/jobm.2 01800039

Fujiwara A, Fujisawa M, Hamasaki R, Kawasaki T, Fujie M, Yamada T (2011) Biocontrol of Ralstonia solanacearum by treatment with lytic bacteriophages. Appl Environ Microbiol 77(12):4155-4162. https://doi.org/10.1128/AEM.02847-10

Goodridge L, Gallaccio A, Griffiths MW (2003) Morphological, host range, and genetic characterization of two coliphages. Appl Environ Microbiol 69(9): 5364-5371. https://doi.org/10.1128/aem.69.9.5364-5371.2003

Iriarte FB, Balogh B, Momol MT, Smith LM, Wilson M, Jones JB (2007) Factors affecting survival of bacteriophage on tomato leaf surfaces. Appl Environ Microbiol 73(6):1704-1711. https://doi.org/10.1128/AEM.02118-06

Iriarte FB, Obradović A, Wernsing MH, Jackson LE, Balogh B, Hong JA, Momol MT, Jones JB, Vallad GE (2012) Soil-based systemic delivery and phyllosphere in vivo propagation of bacteriophages. Bacteriophage 2:e23530. https://doi. org/10.4161/bact.23530

Jones JB, Vallad GE, Iriarte FB, Obradović A, Wernsing MH, Lee E (2018) Considerations for using bacteriophages for plant disease control. Bacteriophage 2(4):208-214. https://doi.org/10.4161/bact.23857

Kaistha SD, Umrao PD, Sagar SS (2018) Bacteriophages as biopesticides. J. Pesticides \& Biofertilizers:1-5. Retrieved on 4 September 2021. https://www.a uctoresonline.org/journals/pesticides-and-bio-fertilizers/archive/108.

Kalpage MD, De Costa DM (2014) Isolation of bacteriophages and determination of their efficiency in controlling Ralstonia solanacearum causing bacterial wilt of tomato. Trop Agric Res 26(1):140-151. https://doi.org/10.4038/tar.v26i1.8079

Kempe J, Sequeira L (1983) Biological control of bacterial wilt of potatoes: attempts to induce resistance by treating tubers with bacteria. Plant Dis 67(5):499-503. https://doi.org/10.1094/PD-67-499

Kropinski AM, Mazzocco A, Waddell TE, Lingohr E, Johnson RP (2009) Enumeration of bacteriophages by double agar overlay plaque assay. Methods Mol Biol 501:69-76. https://doi.org/10.1007/978-1-60327-164-6_7

Milling A, Babujee L, Allen C (2011) Ralstonia solanacearum extracellular polysaccharide is a specific elicitor of defense responses in wilt-resistant tomato plants. PLoS One 6(1):e15853. https://doi.org/10.1371/journal.pone. 0015853

Mina IR, Jara NP, Criollo JE, Castillo JA (2019) The critical role of biofilms in bacterial vascular plant pathogenesis. Plant Pathol 68(8):1439-1447. https:// doi.org/10.1111/ppa.13073

Minh Tran T, Maclntyre A, Khokhani D, Hawes M, Allen C (2016) Extracellular DNases of Ralstonia solanacearum modulate biofilms and facilitate bacterial wilt virulence. Environ Microbiol 18(11):4103-4117. https://doi.org/10.1111/14 62-2920.13446

Mori Y, Hosoi Y, Ishikawa S, Hayashi K, Asai YU, Ohnishi H, Shimatani M, Inoue K, Ikeda K, Nakayashiki H, Nishimura Y, Ohnishi K, Kiba A, Kai K, Hikichi Y (2018) Ralfuranones contribute to mushroom-type biofilm formation by Ralstonia solanacearum strain OE1-1. Mol Plant Pathol 9(4):975-985. https://doi.org/1 $0.1111 / \mathrm{mpp} .12583$

Mori Y, Inoue K, Ikeda K, Nakayashiki H, Higashimoto C, Ohnishi K, Kiba A, Hikichi Y (2016) The vascular plant-pathogenic bacterium Ralstonia solanacearum produces biofilms required for its virulence on the surfaces of tomato cells adjacent to intercellular spaces. Mol Plant Pathol 17(6):890-902. https://doi. org/10.1111/mpp.12335

Murugaiyan S, Bae JY, Wu J, Lee SD, Um HY, Choi HK, Chung E, Lee JH, Lee SW (2011) Characterization of filamentous bacteriophage PE226 infecting Ralstonia solanacearum strains. J Appl Microbiol 110(1):296-303. https://doi. org/10.1111/j.1365-2672.2010.04882.x 
Pires DP, Oliveira H, Melo LDR, Sillankorva S, Azeredo J (2016) Bacteriophageencoded depolymerases: their diversity and biotechnological applications. Appl Microbiol Biotechnol 100(5):2141-2151. https://doi.org/10.1007/s00253015-7247-0

Prakasha A, Grice ID, Kumar KSV, Sadashiva MP, Shankar HN, Umesha S (2017) Extracellular polysaccharide from Ralstonia solanacearum; a strong inducer of eggplant defense against bacterial wilt. Biol Control 110:107-116. https://doi. org/10.1016/j.biocontrol.2017.04.012

Ramesh R, Achari GA, Gaitonde S (2014) Genetic diversity of Ralstonia solanacearum infecting solanaceous vegetables from India reveals the existence of unknown or newer sequevars of phylotype I strains. Eur J Plant Pathol 140(3):543-562. https://doi.org/10.1007/s10658-014-0487-5

Safni I, Cleenwerck I, De Vos P, Fegan M, Sly L, Kappler U (2014) Polyphasic taxonomic revision of the Ralstonia solanacearum species complex: proposal to emend the descriptions of Ralstonia solanacearum and Ralstonia syzygii and reclassify current $R$. syzygii strains as Ralstonia syzygii s. Int J Syst Evol Microbiol 64(Pt_9):3087-3103. https://doi.org/10.1099/ijs.0.066712-0

Sagar SS, Kumar R, Kaistha SD (2017) Efficacy of phage and ciprofloxacin cotherapy on the formation and eradication of Pseudomonas aeruginosa biofilms. Arab J Sci Eng 42(1):95-103. https://doi.org/10.1007/s13369-016-21 94-3

Singh N, Phukan T, Sharma PL, Kabyashree K, Barman A, Kumar R, Sonti RV, Genin S, Ray SK (2018) An innovative root inoculation method to study Ralstonia solanacearum pathogenicity in tomato seedlings. Phytopathology 108(4): 436-442. https://doi.org/10.1094/PHYTO-08-17-0291-R

Umrao P, Kumar V, Sagar S, Kaistha SD (2020) Bacteriophage control for Pseudomonas aeruginosa biofilm formation and eradication. In: Gupta N, Gupta V (eds) Experimental protocols in biotechnology. Humana Press, New York, pp 119-137. https://doi.org/10.1007/978-1-0716-0607-0_7

Vu NT, Oh C-S (2020) Bacteriophage usage for bacterial disease management and diagnosis in plants. Plant Pathol J 36:204-217. https://doi.org/10.5423/ pp.r.r. 04.2020 .0074

Wang X, Wei Z, Yang K, Wang J, Jousset A, Xu Y, Shen Q, Friman V-P (2019) Phage combination therapies for bacterial wilt disease in tomato. Nat Biotechnol 37(12):1513-1520. https://doi.org/10.1038/s41587-019-0328-3

Wei C, Liu J, Maina AN, Mwaura FB, Yu J, Yan C, Zhang R, Wei H (2017) Developing a bacteriophage cocktail for biocontrol of potato bacterial wilt. Virol Sin 32(6):476-484. https://doi.org/10.1007/s12250-017-3987-6

Yadeta KA, Thomma BPHJ (2013) The xylem as battleground for plant hosts and vascular wilt pathogens. Front. Plant Sci. 4:97. https://doi.org/10.3389/fpls.2 013.00097

Yamamoto KR, Alberts BM, Benzinger R, Lawhorne L, Treiber G (1970) Rapid bacteriophage sedimentation in the presence of polyethylene glycol and its application to large-scale virus purification. Virology 40(3):734-744. https:// doi.org/10.1016/0042-6822(70)90218-7

Ye M, Sun M, Huang D, Zhang Z, Zhang H, Zhang S, Hu F, Jiang X, Jiao W (2019) A review of bacteriophage therapy for pathogenic bacteria inactivation in the soil environment. Environ Int 129:488-496. https://doi.org/10.1016/j. envint.2019.05.062

Yuliar NYA, Toyota K (2015) Recent trends in control methods for bacterial wilt diseases caused by Ralstonia solanacearum. Microbes Environ 30(1):1-11. https://doi.org/10.1264/jsme2.ME14144

\section{Publisher's Note}

Springer Nature remains neutral with regard to jurisdictional claims in published maps and institutional affiliations.

\section{Submit your manuscript to a SpringerOpen ${ }^{\circ}$ journal and benefit from:}

- Convenient online submission

- Rigorous peer review

- Open access: articles freely available online

- High visibility within the field

- Retaining the copyright to your article

Submit your next manuscript at $\boldsymbol{\nabla}$ springeropen.com 